\title{
Aspects regarding the prediction of earth electrode corrosion in the soil of Timisoara
}

\author{
Ștefan Pavel ${ }^{1, *}$, Ioan-Bogdan Pascu ${ }^{1}$, Bogdan-Ovidiu Țăranu ${ }^{2}$, Oana-Alexandra Grad ${ }^{1}$, Romeo Negrea $^{3}$, and \\ Ioan-Silviu Doboși ${ }^{4}$ \\ ${ }^{1}$ Politehnica University Timisoara - Research Institute for Renewable Energies, 300501 Timisoara, Romania \\ ${ }^{2}$ The National Institute of Research and Development for Electrochemistry and Condensed Matter 300054 Timisoara, Romania \\ ${ }^{3}$ Politehnica University Timisoara, Department of Mathematics, 300223 Timisoara, Romania \\ ${ }^{4}$ S.C. Dosetimpex S.R.L., 0714 Timisoara, Romania
}

\begin{abstract}
Corrosion prediction of galvanized steel ground electrodes in the soil of Timisoara represents an area of interest for ensuring the good functioning of the earth electrodes, the safety of the electrical installation, and of the lightning rodes. Taking in the account that the soil is exposed to different kind of pollutants which have an effect on the ground electrodes we consider that a research is needed in this area.
\end{abstract}

\section{Introduction}

The city of Timisoara is located in the Banat Plain in western Romania, and has the following geographical coordinates: latitude $450 \quad 47^{\prime} 58^{\prime \prime} \mathrm{N}$

and the longitude $21017^{\prime} 38^{\prime \prime} \mathrm{E}$ [1]. Historically, the city is mentioned documentary in the year 1212 or 1266 , but the hearth of the city settlement attest to the presence and human activity since the neolithic period, due to the high fertility of the soil and a military strategic position, being surrounded by marsh and several water channels. The soil [2] is of type: chernozem, gleysol, leachate, reddish brown. And local soils: swamps and solonetz with medium-fine texture, low - medium porosity, and low permeability.

Corrosion in the soil of metals is accentuated by the following factors:

$>$ Resistivity, $\rho$ in $[\Omega \bullet m]$;

$>\mathrm{pH}$ (potential of hydrogen $0 \leq \mathrm{pH}<7 \Rightarrow$ acid $\mathrm{pH}, \mathrm{pH}=7 \Rightarrow$ neutral $\mathrm{pH}, 7<\mathrm{pH} \leq 14 \Rightarrow$ alkaline $\mathrm{pH}$ );

$>$ Temperature, $\mathrm{T}$ in $[0 \mathrm{C}]$;

$>$ Humidity, $[\%]$;

$>$ The chemical composition of the electrolytes.
The definition of earthing installation: the earthing installation is the assembly of electrical conductors through which the link with the soil is secured[3]. In a building, the connection of every metallic part of the building, and the exposed conductive parts of the equipments to the building earthing socket prevents the accidental occurrence of dangerous voltages between two metallic parts simultaneously.[4] The earthing installation ensures the protection of electrical equipments and the building itself against lightning strikes, the limitation of electromagnetic perturbations, and the safety of humans and animals by limiting the pitch voltages [5]. In Cap.5 from Indicativ I7/2011 [6] subcap.5.5, Sisteme de legare la pământ pct 5.5.7. The earth socket is made of one or more electrodes (earth electrodes). The materials and dimensions of the electrodes (earth electrodes) must be chosen to withstand the corrosion and mechanical stress. The material from which the electrodes and the surface elements are made represents an important role. Form, diamater [mm], the section [m2], thickness [mm], and the thickness of coating (Zinc) of the material $[\mu \mathrm{m}]$.

\section{Soil properties at the sampling sites}

A number of 12 soil samples from Timisoara were taken from the areas presented in Table 1. The soil samples were collected at the temperature of $10 \mathrm{oC}$ using the following instruments:

- Stelzner probe made of stainless steel, and a long steel tubular probe of $1.5-2 \mathrm{~m}$, graduated from 10 to $10 \mathrm{~cm}$, and the truncated inner tube channel; 
- Soil testing kit, which contains: a glass with hydrochloric acid $1 / 3$ concentration, barium chloriden/10 for the identification of sulphites, phenolphthalein, $1 \%$ ferricyanide, $5 \%$ sodium salicylate, field $\mathrm{pH}$ - meter, various test tubes, funnel, paper filter, palette knife, bags, cylinders, cans, labels and measuring roulette;

○ Shovel, geological hammer;

- Wooden boxes, cardboard, and plastic boxes;

- Altimeter and level bar;

Table 1. Sampling areas.

\begin{tabular}{|c|c|}
\hline & Sampling area \\
\hline 1 & Former sugar factory (a) \\
\hline 2 & Former sugar factory (b) \\
\hline 3 & Penitenciary - Popa Șapcă street (a) \\
\hline 4 & Penitenciary - Popa Șapcă street (b) \\
\hline 5 & Calea Buziașului \\
\hline 6 & Piața Victoriei \\
\hline 7 & Calea Torontalului \\
\hline 8 & Calea Torontalului-Airport use area \\
\hline 9 & Strada Lt.Ovidiu Balea \\
\hline 10 & Calea Aradului-U.S.A.M.V.B.T \\
\hline 11 & Calea Aradului (a) \\
\hline 12 & Calea Aradului (b) \\
\hline
\end{tabular}

Each soil sample was taken from $0-2 \mathrm{~m}$ depth. The following soil characteristics have been analysed: texture [\%], specific density [g/cm3], apparent density [g/cm3], total porosity $[\%]$, aeration porosity $[\%]$, compaction degree $[\%]$, hygroscopic coefficient [\%], wilting coefficient $[\%]$, field capacity $[\%]$, total capcity, available water capacity [\%], maximum yield capacity $[\%]$, hydraulic capacity $[\mathrm{mm} / \mathrm{h}], \mathrm{pH}$ in $\mathrm{H} 2 \mathrm{O}$, carbonates [CaCO3\%], humus $[\%]$, humus reserve $[\mathrm{t} / \mathrm{ha}]$, exchangeable hydrogen (organic acids - direct source of $\mathrm{SH}$ [SH·me], cation exchange capacity[T.me/100g], base saturation degree $[\mathrm{V}, \cdot \%]$, base exchange $[\mathrm{SB} . \mathrm{me} /$ $100 \mathrm{~g}$ soil].

The ones selected in this study are: total porosity[\%] (capillary porosity and non-capillary porosity (of aeration)) and the hygroscopic coefficient[\%], as elements that lead to the corrosion of earthing electrodes and their connections. The element which determines the electrical resistance of a earthing socket (besides the length of the electrodes) is the resistivity $\rho$ of the soil. The soil is not homogeneous, and the deeper layers have a more stable and lower resistivity. The resistivity $\rho$ characteristics of the soil are presented in Table 2, Table 3, Table 4 and Table 5.

Table 2. [7]

\begin{tabular}{|c|c|c|}
\hline Soil type & $\begin{array}{c}\text { Recommen } \\
\text { ded values } \\
\text { for } \\
\text { calculus } \\
\rho[\Omega \mathrm{m}]\end{array}$ & $\begin{array}{c}\text { Soil } \\
\text { conductivit } \\
\mathbf{y \lambda}\left[\mathrm{mS}_{\mathrm{x}} \mathrm{m}^{-}\right. \\
\left.{ }^{1}\right]\end{array}$ \\
\hline $\begin{array}{c}\text { Clay, peat(very } \\
\text { damp) }\end{array}$ & 20,00 & 50 \\
\hline Chernozem & 50,00 & 20 \\
\hline $\begin{array}{c}\text { Clay containing } \\
\text { iron sulphide }\end{array}$ & 10,00 & 100 \\
\hline Arable land & 50,00 & 20 \\
\hline Argil & 80,00 & 125 \\
\hline Soil with gravel & 200,00 & 5 \\
\hline Loess, forest soil & 250,00 & 4 \\
\hline Sandy soil & 300,00 & 3,3 \\
\hline Very damp sand & 400,00 & 2,5 \\
\hline Ballast with soil & 1000,00 & 1 \\
\hline Sand and sand \\
with gravel
\end{tabular}

Table 3. Sampling areas.

\begin{tabular}{|l|c|}
\hline \multicolumn{1}{|c|}{ Soil type } & $\begin{array}{c}\text { Recommended values for } \\
\text { calculus } \rho[\Omega \mathrm{m}]\end{array}$ \\
\hline Swampy soil, muddy & $1-30$ \\
\hline Silt & $20-100$ \\
\hline Humus,plant soil & $10-150$ \\
\hline Peat bog & $5-100$ \\
\hline Light argil & 50 \\
\hline Marl, compact argil & $100-200$ \\
\hline Jurassic marl & $30-40$ \\
\hline Sandy argil & $50-500$ \\
\hline Silica sand & $200-300$ \\
\hline Stony soil & $1.500-3.000$ \\
\hline $\begin{array}{l}\text { Stony soil covered in } \\
\text { grass }\end{array}$ & $300-500$ \\
\hline Chalky soil & $100-300$ \\
\hline Calcareous stone & $1000-5000$ \\
\hline Fine limestone gravel & $500-1000$ \\
\hline Marl, shale clay & $50-300$ \\
\hline Mica schist, schists & 800 \\
\hline Graniteand sandstone & $1500-10000$ \\
\hline $\begin{array}{l}\text { Modified granite and } \\
\text { sandstone }\end{array}$ & \\
\hline
\end{tabular}




\begin{tabular}{|l|c|c|c|c|c|c|c|c|c|}
\hline Texture & \multicolumn{2}{|l}{} & & & & \\
\hline Depth [cm] & $\mathbf{0 - 5}$ & $\mathbf{- 2 5}$ & $\mathbf{- 4 2}$ & $\mathbf{- 5 4}$ & $\mathbf{- 7 4}$ & $\mathbf{- 8 8}$ & $\mathbf{- 1 1 0}$ & $\mathbf{- 1 4 5}$ & $\mathbf{- 2 0 0}$ \\
\hline $\begin{array}{l}\text { Coarse sand (2-0.2 } \\
\text { mm) \% }\end{array}$ & 4,8 & 4,2 & 6,4 & 3,1 & 2,0 & 2,0 & 1,7 & 1,7 & 9 \\
\hline $\begin{array}{l}\text { Fine sand (0.2-0.02 } \\
\text { mm) \% }\end{array}$ & $\mathbf{4 7 , 7}$ & $\mathbf{4 8 , 7}$ & $\mathbf{4 4 , 0}$ & $\mathbf{4 5 , 3}$ & $\mathbf{4 4 , 3}$ & $\mathbf{4 6 , 2}$ & $\mathbf{5 0 , 8}$ & $\mathbf{5 6 , 7}$ & $\mathbf{6 5 , 8}$ \\
\hline $\begin{array}{l}\text { Dust (0.02-0.002 mm) } \\
\text { \% }\end{array}$ & 24,3 & 21,7 & 22,8 & 21,9 & 20,2 & 21,9 & 21,7 & 19,7 & 10,4 \\
\hline $\begin{array}{l}\text { Argil 2 (under 0.002 } \\
\text { mm) \% }\end{array}$ & $\mathbf{2 3 , 2}$ & $\mathbf{2 5 , 4}$ & $\mathbf{2 6 , 8}$ & $\mathbf{2 9 , 7}$ & $\mathbf{3 3 , 5}$ & $\mathbf{2 9 , 9}$ & $\mathbf{2 5 , 8}$ & $\mathbf{2 1 , 9}$ & $\mathbf{1 4 , 8}$ \\
\hline $\begin{array}{l}\text { Physical argil (sub } \\
\mathbf{0 . 0 1} \mathbf{m m} \%\end{array}$ & $\mathbf{3 6 , 6}$ & $\mathbf{3 7 , 6}$ & $\mathbf{3 9 , 1}$ & $\mathbf{4 1 , 2}$ & $\mathbf{4 4 , 1}$ & $\mathbf{4 2 , 0}$ & $\mathbf{3 7 , 0}$ & $\mathbf{3 1 , 9}$ & $\mathbf{2 0 , 0}$ \\
\hline $\begin{array}{l}\text { Soil properties } \\
\text { Total porosity \% }\end{array}$ & 55,0 & 50,6 & 42,1 & 45,3 & 47,3 & - & - & - & - \\
\hline $\begin{array}{l}\text { Hygroscopic } \\
\text { coefficient \% }\end{array}$ & 4,86 & 5,15 & 5,46 & 6,30 & 7,06 & - & - & - & - \\
\hline
\end{tabular}

Table 4. [10] Characteristics of the soil sample

Table 5.[10] Characteristics of the soil sample no. 1 (b)

\begin{tabular}{|l|c|c|c|c|c|c|c|c|c|}
\hline Texture & \multicolumn{3}{|l}{} & & & & & \\
\hline Depth [cm] & $\mathbf{0 - 5}$ & $\mathbf{- 2 5}$ & $\mathbf{- 4 2}$ & $\mathbf{- 5 4}$ & $\mathbf{- 7 4}$ & $\mathbf{- 8 8}$ & $\mathbf{- 1 1 0}$ & $\mathbf{- 1 4 5}$ & $\mathbf{- 2 0 0}$ \\
\hline $\begin{array}{l}\text { Coarse sand (2-0.2 } \\
\text { mm) \% }\end{array}$ & 2,4 & 2,8 & 3,0 & 1,4 & 2,6 & 1,8 & 0,5 & 0,2 & 1,6 \\
\hline $\begin{array}{l}\text { Fine sand (0.2-0.02 } \\
\text { mm) \% }\end{array}$ & $\mathbf{4 6 , 6}$ & $\mathbf{4 3 , 8}$ & $\mathbf{4 4 , 0}$ & $\mathbf{3 6 , 1}$ & $\mathbf{4 5 , 6}$ & $\mathbf{4 9 , 3}$ & $\mathbf{4 1 , 1}$ & $\mathbf{5 0 , 7}$ & $\mathbf{5 7 , 5}$ \\
\hline $\begin{array}{l}\text { Dust (0.02-0.002 mm) } \\
\text { \% }\end{array}$ & 22,8 & 22,7 & 22,3 & 19,9 & 19,6 & 21,7 & 30,6 & 26,6 & 21,8 \\
\hline $\begin{array}{l}\text { Argil 2 (sub 0.002 } \\
\text { mm) \% }\end{array}$ & $\mathbf{2 8 , 2}$ & $\mathbf{3 0 , 7}$ & $\mathbf{3 0 , 7}$ & $\mathbf{4 2 , 6}$ & $\mathbf{3 2 , 2}$ & $\mathbf{2 7 , 2}$ & $\mathbf{2 7 , 9}$ & $\mathbf{2 2 , 5}$ & - \\
\hline $\begin{array}{l}\text { Physical argil (sub } \\
\mathbf{0 . 0 1} \text { mm) \% }\end{array}$ & $\mathbf{4 0 , 9}$ & $\mathbf{4 2 , 9}$ & $\mathbf{4 2 , 1}$ & $\mathbf{5 3 , 7}$ & $\mathbf{4 2 , 9}$ & $\mathbf{3 8 , 1}$ & $\mathbf{4 3 , 0}$ & $\mathbf{3 5 , 3}$ & - \\
\hline $\begin{array}{l}\text { Soil properties } \\
\text { Total porosity \% }\end{array}$ & 50,4 & 49,5 & 45,7 & 43,6 & 45,7 & - & - & - & - \\
\hline $\begin{array}{l}\text { Hygroscopic } \\
\text { coefficient \% }\end{array}$ & 5,93 & 6,53 & 6,83 & 9,47 & 6,8 & - & - & - & - \\
\hline
\end{tabular}

Resulting that sand and argil (pottery clay) predominate the soil composition of the sample no.1(a)and(b)

\section{Materials-specimens of steel used for obtaining the earth electrodes}

An important role of the earth socket it represents the resistance RL, respective the metallic part of the earth socket: vertically positioned earth electrodes, and the metal strip horizontally positioned both in the ground and above ground. As materials used for making the earth electrodes, we mention:

Corner profiled steel, T, I, and the metal strip unprotected;
- Corner profiled steel, T, I, and the metal strip protected through galvanizing;

Corner profiled steel, T, I, and the metal strip protected with bentonite;

- Unprotected steel pipes;

Galvanized steel pipes;

- $\quad$ Round steel unprotected and galvanized;

- Round steel protected with bentonite;

- Round steel unprotected and embedded in concrete

- Copper (pipes, plates, band);

- Stainless steel.

In order to perform the corrosion measurements of the earth electrodes, the materials presented in Table 6 were used. 
Table. 6 Materials features

\begin{tabular}{|c|c|c|c|c|c|}
\hline \multirow{2}{*}{\multicolumn{2}{|c|}{ Material }} & \multirow{3}{*}{$\begin{array}{l}\text { Profile } \\
\text { Cross }\end{array}$} & \multicolumn{2}{|c|}{ Protective coating } & \multirow{3}{*}{\begin{tabular}{|l} 
Dimensions \\
$\begin{array}{l}50 \times 50 \times 3 \mathrm{~mm} \\
\mathrm{~L}=1,5 \mathrm{~m}\end{array}$
\end{tabular}} \\
\hline & & & \multirow{2}{*}{\begin{tabular}{|l} 
protected \\
$\begin{array}{l}\text { galvanize } \\
\mathrm{d}^{*}(1)\end{array}$
\end{tabular}} & \multirow{2}{*}{ unprotected } & \\
\hline 1 & Steel & & & & \\
\hline 2 & Steel & Cross & - & unprotected & $\begin{array}{l}50 \times 50 \times 3 \mathrm{~mm} \\
\mathrm{~L}=1,5 \mathrm{~m}\end{array}$ \\
\hline 3 & Steel & Band & $\begin{array}{l}\text { galvanize } \\
\mathrm{d}_{*(3)}\end{array}$ & & $\begin{array}{l}40 \times 4 \mathrm{~mm}, \\
\mathrm{~L}=1 \mathrm{~m}\end{array}$ \\
\hline 4 & Steel & Round & $\begin{array}{l}\text { galvanize } \\
\mathrm{d}^{*(4)}\end{array}$ & & $\begin{array}{l}\mathrm{D}=8 \mathrm{~mm}, \\
\mathrm{~L}=1 \mathrm{~m}\end{array}$ \\
\hline 5 & Steel & Round & - & unprotected & $\begin{array}{l}\mathrm{D}=8 \mathrm{~mm}, \\
\mathrm{~L}=1 \mathrm{~m}\end{array}$ \\
\hline 6 & Coppe & Pipe & - & unprotected & $\begin{array}{l}18 \times 0.7 \mathrm{~mm}, \\
=0.23 \mathrm{~m}\end{array}$ \\
\hline 7 & Coppe & Plate & - & unprotected & $\begin{array}{c}200 \times 52 \times 0.5 \\
\mathrm{~mm}\end{array}$ \\
\hline
\end{tabular}

Obs:

- $\quad{ }^{*}(1) ;{ }^{*}(3) ;{ }^{*}(4)$; the thickness of the zinc layer was determined by the magnetic method (ISO 2178); The lifetime of Hot-dip galvanization products is based on the thickness of the coating and the corrosion of the atmosphere. [11]

Samples 1 and 2 are conformable with:

- $\quad$ EN 10056-1 Manufacture dimensions;

- $\quad$ DIN 17100/EN 10025 Material quality;

- $\quad$ EN 10056-1 Manufacture tolerances;

- $\quad$ EN 10163-1 Surface appearance;

- $\quad$ EN 10204 Quality certificate.

Sample 3 is conformable with:

- $\quad$ EN 10058 Manufacture dimensions;

- $\quad$ EN 10204 Material quality;

- $\quad$ EN 10058 Manufacture tolerances;

- $\quad$ EN 10163-3 Surface appearance;

- $\quad$ EN 10204 Quality certificate.

Samples 4 and 5 are conformable with:

- $\quad$ EN 10060 Manufacture dimension

- $\quad$ EN 10025-2 Material quality;

- $\quad$ EN 10060 Manufacture tolerances;

- $\quad$ EN 10221 Surface appearance;

- $\quad$ EN 10204 Quality certificate;

Samples 6 and 7 are conformable with:

- $\quad$ SR EN 12449:2012 Copper and copper alloys. Seamless round pipes for general applications.

Note that M8 nut bolt (electrolytic zinc coating), and flange catch lug (electrolytic zinc coating) from Table 8 . are component parts of the vertically positioned electrode which is part of the earthing installation.
Regarding the corrosion of steel in the soil with and without zinc coating, the authors of the material [14] used the following methods: Tafel equation with high and low humidity
(the Tafel equation is an electrochemical kinetics equation related to the speed of an electrochemical reaction.[1] The Tafel equation was first experimentally deducted, and later proved to have a theoretical justification. The equation is named after the swiss chemist Julius Tafel)[15];

Gravimetric method with high and low humidity (Gravimetric analysis, also called gravimetry ${ }^{[1]}$, brings together all analytical methods used in analytical chemistry for the quantitative determination of an analyte (the compounds of interest) based on its mass. ${ }^{[2]}$ The principle on which gravimetric analysis is based is the mass determination of a compound derived from the sample analyte, and on the basis of the chemical reactions to which it has been reached, the mass of the respective analyte can be determined. For this reason it is necessary to know in detail the chemical processes that take place, and these must be total (quantitative)) [16].

Table 8.

\begin{tabular}{|c|c|c|c|}
\hline \multirow[t]{2}{*}{ Sample } & \multirow{2}{*}{$\begin{array}{l}\text { Zinc layer } \\
\text { thickness } \\
{[\mu \mathrm{m}]} \\
\text { before the } \\
\text { exposure } \\
\text { to the salt } \\
\text { mist test }\end{array}$} & \multicolumn{2}{|c|}{$\begin{array}{l}\text { The thickness of the layer of zinc } \\
\qquad[\mu \mathrm{m}]\end{array}$} \\
\hline & & $\begin{array}{c}\text { After 30 } \\
\text { days of } \\
\text { exposure to } \\
\text { the salt } \\
\text { mist test }\end{array}$ & $\begin{array}{l}\text { After } 60 \text { days of } \\
\text { exposure to the } \\
\text { salt mist test }\end{array}$ \\
\hline 1 & $84 \div 108$ & $54 \div 90$ & $60 \div 86$ \\
\hline 3 & $50 \div 54$ & $29 \div 31$ & $3 \div 24$ \\
\hline 4 & $58 \div 68$ & $34 \div 54$ & $24 \div 32$ \\
\hline $\begin{array}{l}\text { Screw } \\
\text { and nut } \\
\text { M8 } \\
\text { (electrol } \\
\text { ytic zinc } \\
\text { coating) }\end{array}$ & $27 \div 43$ & $20 \div 38$ & $17 \div 18$ \\
\hline $\begin{array}{c}\text { Flange } \\
\text { Catch lug } \\
\text { (electrolyti } \\
\text { c zinc } \\
\text { coating) }\end{array}$ & $23 \div 49$ & $20 \div 36$ & $15 \div 17$ \\
\hline
\end{tabular}

The soil sample that was used for the experiment is theArgil (pottery clay)(According to the specialty literature with the resistivity $\rho=40 \Omega \mathrm{m}$, considered a poorly aggressive environment, and $\rho=20 \Omega \mathrm{m}$, considered moderately corrosive environment). The 
results of the analyses carried out by the two methods are presented in Table 9 and Table 10.

\section{Table 9. Analyses results}

\begin{tabular}{|l|c|c|c|}
\hline Material & Humidity & $\begin{array}{c}\text { Corrosion } \\
\text { potential }(\boldsymbol{m} \boldsymbol{V} \\
\mathbf{C u} / \mathbf{C u S O 4})\end{array}$ & $\begin{array}{l}\text { Corr } \\
\text { osion } \\
\text { curre } \\
\mathbf{n t} \\
\mathbf{d e n s i}\end{array}$ \\
\hline $\begin{array}{l}\text { Galvanized } \\
\text { steel }\end{array}$ & low & $-840,8$ & 0,00477 \\
\cline { 2 - 4 } & high & -1047.0 & 0.05270 \\
\hline Carbon steel & low & $-305,7$ & 0,00029 \\
\cline { 2 - 4 } & high & -705.8 & 0,00346 \\
\hline
\end{tabular}

Table 10. Analyses results

\begin{tabular}{|c|c|c|c|c|}
\hline \multicolumn{5}{|c|}{ Corrosion rate (mm/year) } \\
\hline Material & $\begin{array}{l}15 \\
\text { days }\end{array}$ & $\begin{array}{l}30 \\
\text { days }\end{array}$ & $\begin{array}{l}45 \\
\text { days }\end{array}$ & $\begin{array}{l}60 \\
\text { days }\end{array}$ \\
\hline $\begin{array}{l}\text { Galvanized } \\
\text { steel-low } \\
\text { humidity }\end{array}$ & $\begin{array}{l}0.00 \\
95 \pm \\
0.00 \\
09\end{array}$ & $\begin{array}{l}0.005 \\
1 \pm 0.0 \\
008\end{array}$ & $\begin{array}{l}0.0 \\
119 \\
\pm 0 . \\
001 \\
3\end{array}$ & $\begin{array}{l}0.003 \\
4 \pm 0.0 \\
003\end{array}$ \\
\hline $\begin{array}{r}\text { Galvanized } \\
\text { steel-high } \\
\text { humidity }\end{array}$ & $\begin{array}{l}0.04 \\
87 \pm \\
0.00 \\
11\end{array}$ & $\begin{array}{l}0.043 \\
4 \pm 0.0 \\
017\end{array}$ & $\begin{array}{l}0.0 \\
441 \\
\pm 0 \text {. } \\
002 \\
0\end{array}$ & $\begin{array}{l}0.039 \\
3 \pm 0.0 \\
008\end{array}$ \\
\hline $\begin{array}{l}\text { Carbon steel- } \\
\text { low humidity }\end{array}$ & $\begin{array}{l}0.21 \\
82 \pm \\
0.00 \\
21\end{array}$ & $\begin{array}{l}0.191 \\
1 \pm 0.0 \\
017\end{array}$ & $\begin{array}{l}0.1 \\
626 \\
\pm 0 . \\
001 \\
2\end{array}$ & $\begin{array}{l}0.120 \\
5 \pm 0.0 \\
015\end{array}$ \\
\hline $\begin{array}{c}\text { Carbon steel- } \\
\text { high } \\
\text { humidity }\end{array}$ & $\begin{array}{l}0.08 \\
63 \pm \\
0.00 \\
13\end{array}$ & $\begin{array}{l}0.060 \\
2 \pm 0.0 \\
006\end{array}$ & $\begin{array}{l}0.0 \\
533 \\
\pm 0 . \\
000 \\
6\end{array}$ & $\begin{array}{l}0.041 \\
9 \pm 0.0 \\
007\end{array}$ \\
\hline
\end{tabular}

In Figure 1 we can see the soil classes existing on the Romanian territory. Figures 2 to 4 show images taken during the measurements.

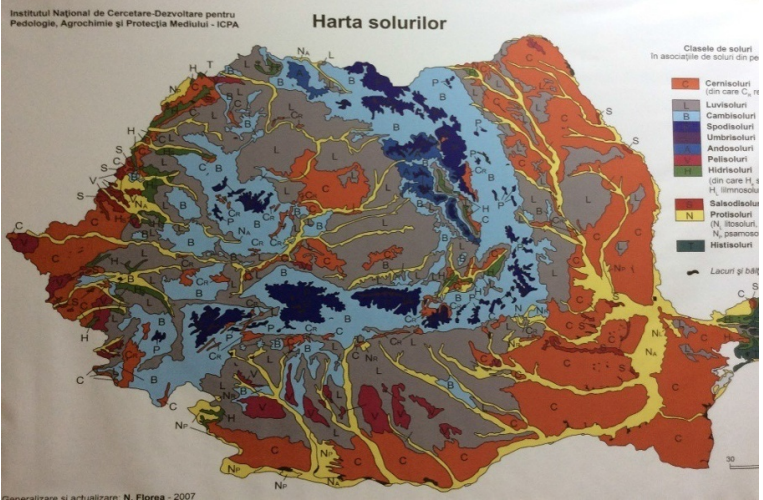

Fig. 1 Map of soil classes in Romania [12]

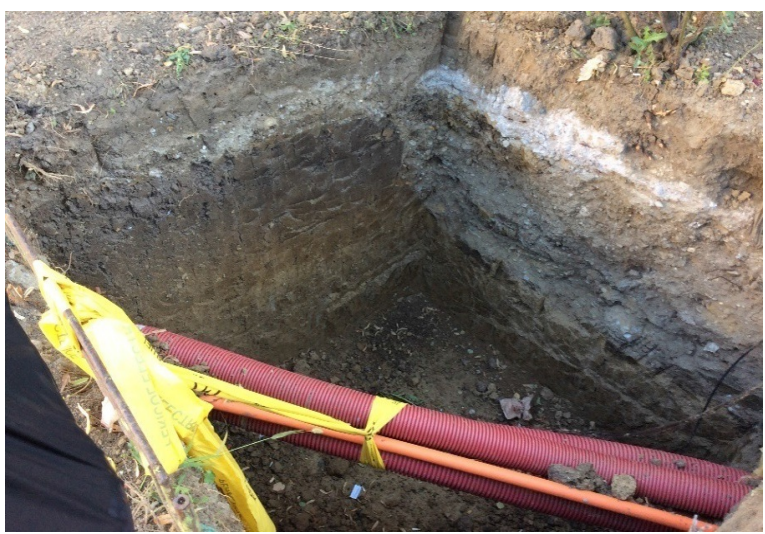

Fig. 2 Soil excavation destined for the installation of a public lighting pillar

\section{Corrosion of steel and copper specimens}

Procedure: The specimens were placed in the DCTC (Dry Corrosion Test Cabinet) and exposed to multiple spray processes, followed by a rest period. A cycle is constituted of a 5 minute spray step followed by a 55 minute rest period. In total, the DCTC test lasted 60 days, with 1440 cycles. The saline solution was prepared by dissolving $1 \mathrm{~kg}$ of sodium chloride in $20 \mathrm{~L}$ of distilled water. The temperature inside the test cabinet was $25 \pm$ $3^{\circ} \mathrm{C}$, both during the spraying process and the rest period. The temperature inside the test cabinet was $25 \pm$ $3^{\circ} \mathrm{C}$, both during the spraying process and the rest period. The temperature inside the test cabinet was $25 \pm$ $3^{\circ} \mathrm{C}$, both during the spraying process and the rest period. The humidifier temperature was $25 \pm 3^{\circ} \mathrm{C}$. The spraying pressure was 1.4 bars, and the sprayed quantity was of $80 \mathrm{~mL} / \mathrm{h} * \mathrm{~m} 3$. The two specimens were turned every 72 hours. The $\mathrm{pH}$ of the saline solution after preparation was 7.37 , and 8.54 at the exit of DCTC.

\subsection{Corrosion of the $\mathrm{Cu}$ specimens}

Two plates and two bars of $\mathrm{Cu}$ - of which a plate and a bar were to be put inside DCTC, and the other plate and the bar served as witnesses - they were weighed before and after the cleaning process.

The cleaning process of the $\mathrm{Cu}$ plates and bars consisted in: Washing with detergent; Rinsed with water and wiped; Washing with a solution of HNO3 5\%; Rinsed 
with water and washed with acetone; Dried in the oven at $40^{\circ} \mathrm{C}$ for 60 minutes.

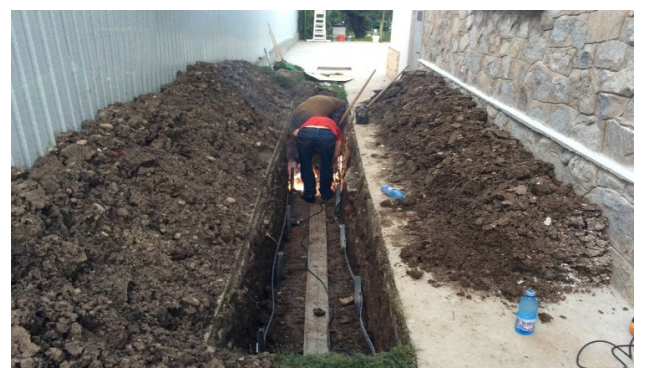

Fig. 3 Earthing installation with vertical electrodes and metal strip from galvanized steel

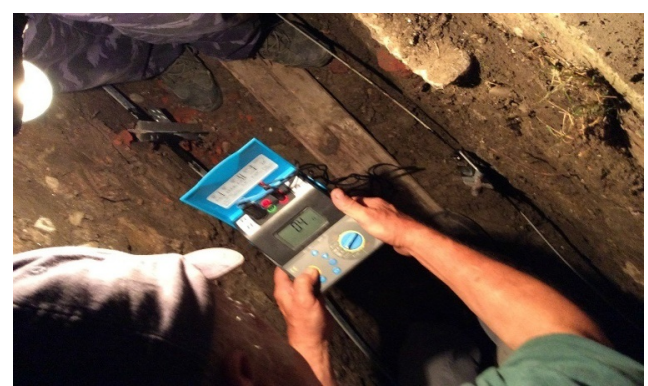

Fig. 4 Earthing installation - measuring the dispersion resistance

Table 11. The mass values of the $\mathrm{Cu}$ specimens before and after the cleaning process

\begin{tabular}{|l|l|l|l|}
\hline $\begin{array}{l}\text { Bars } \\
\text { and } \\
\text { plates of } \\
\text { Cu }\end{array}$ & $\begin{array}{l}\text { Mass before } \\
\text { the cleaning } \\
\text { process }[\mathbf{g}]\end{array}$ & $\begin{array}{l}\text { Mass after } \\
\text { the cleaning } \\
\text { process }[\mathbf{g}]\end{array}$ & $\begin{array}{l}\text { Mass } \\
\text { difference } \\
\text { [g] }\end{array}$ \\
\hline $\begin{array}{l}\text { Witness } \\
\text { plate }\end{array}$ & 44,1329 & 44,0780 & 0,0549 \\
\hline $\begin{array}{l}\text { Testing } \\
\text { plate }\end{array}$ & 43,0605 & 43,0110 & 0,0495 \\
\hline $\begin{array}{l}\text { Witness } \\
\text { bar }\end{array}$ & 64,4325 & 64,3942 & 0,0383 \\
\hline $\begin{array}{l}\text { Testing } \\
\text { bar }\end{array}$ & 64,5093 & 64,4776 & 0,0317 \\
\hline
\end{tabular}
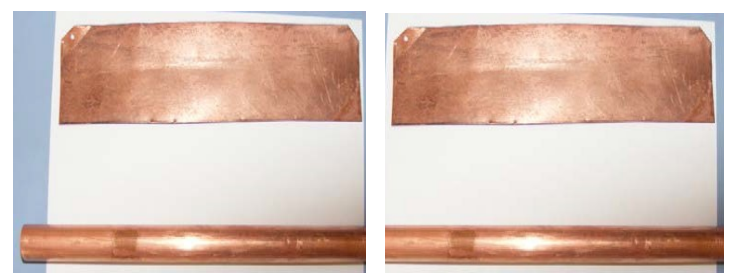

Fig 5. $\mathrm{a}$ and $\mathrm{b}$ - The witness plate and bar. Date: 03.07 .2018

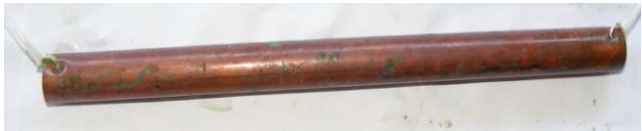

a)

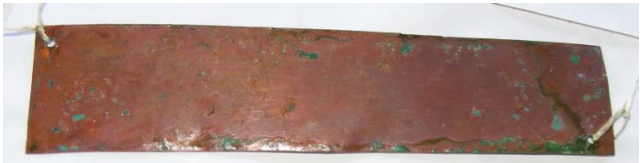

b)

Fig 6. $\mathrm{a}$ and $\mathrm{b}$ - corroded $\mathrm{Cu}$ plate and corroded $\mathrm{Cu}$ bar. Date: 13.07.2018

\subsection{Corrosion of the galvanized steel specimens}

The corrosion study of the galvanized steel specimens was also achieved through the effect of the salt mist, starting from 20.06.2018 until 15.07.2018.
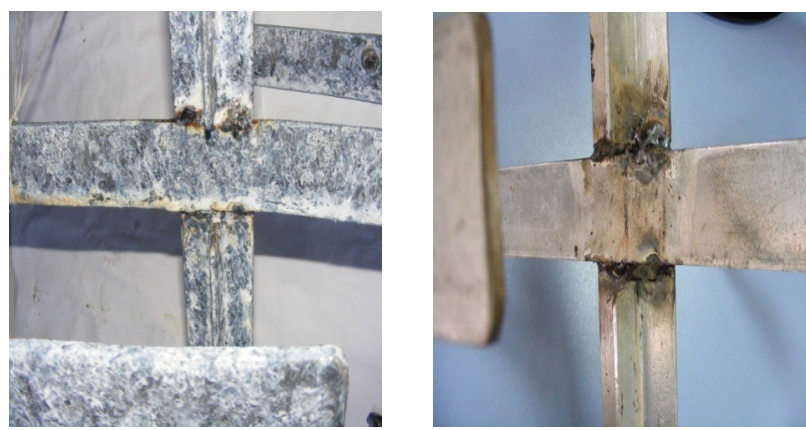

Fig 8. Galvanized steel specimen before and after the DCTC test. Date: 19.06 .2018 - 15.07.2018

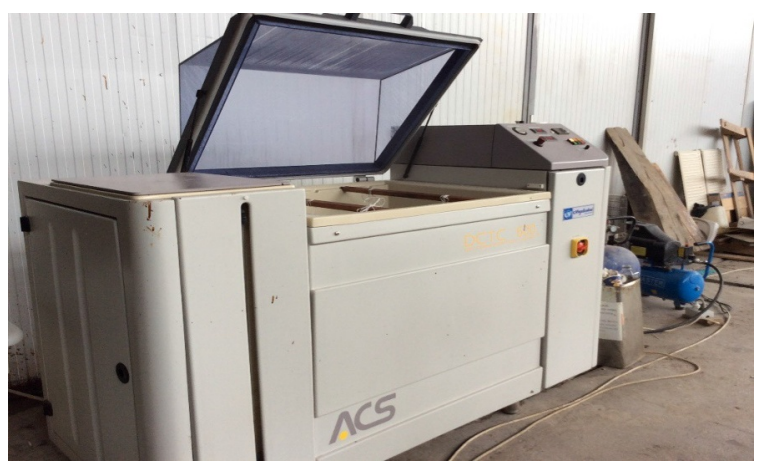

Fig. 9 Dry Corrosion Test Cabinet (DCTC)600 made by Angeloantoni Industrie

\subsection{SEM (scanning electron microscopy) analysis and EDX (energy dispersive X-ray spectroscopy) of the specimens}

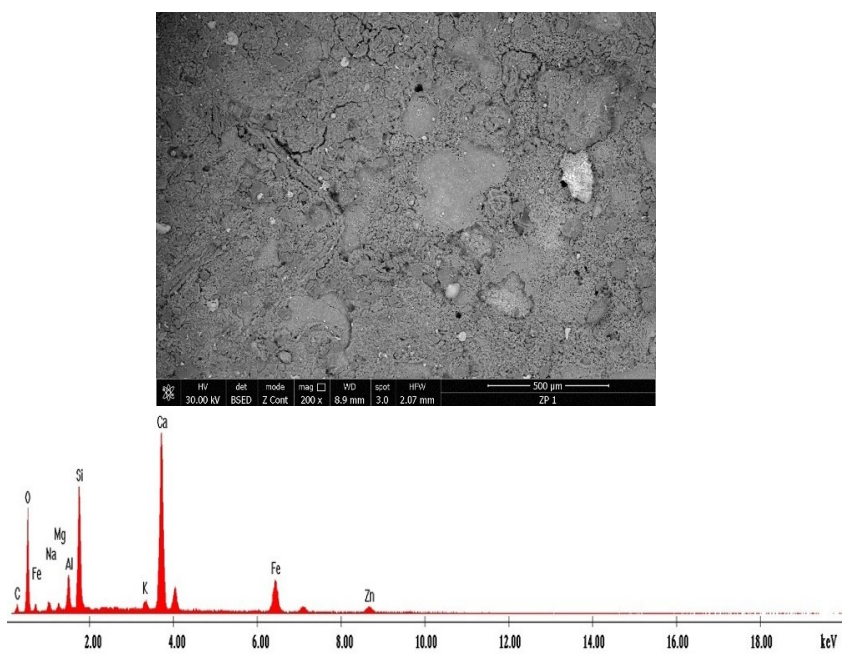

Fig 10. SEM image (up) of the specimen installed in the soil and EDX analysis (down) 


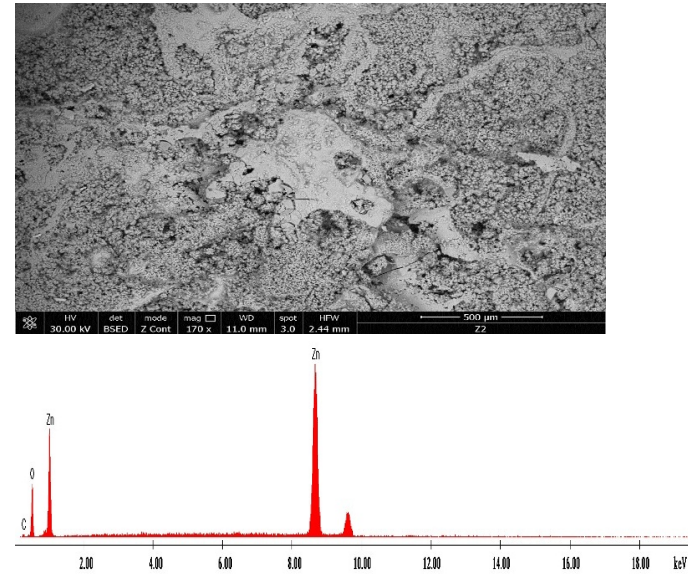

Fig. 11. SEM image (up) of the specimen exposed to the salt mist test and EDX analysis (down)

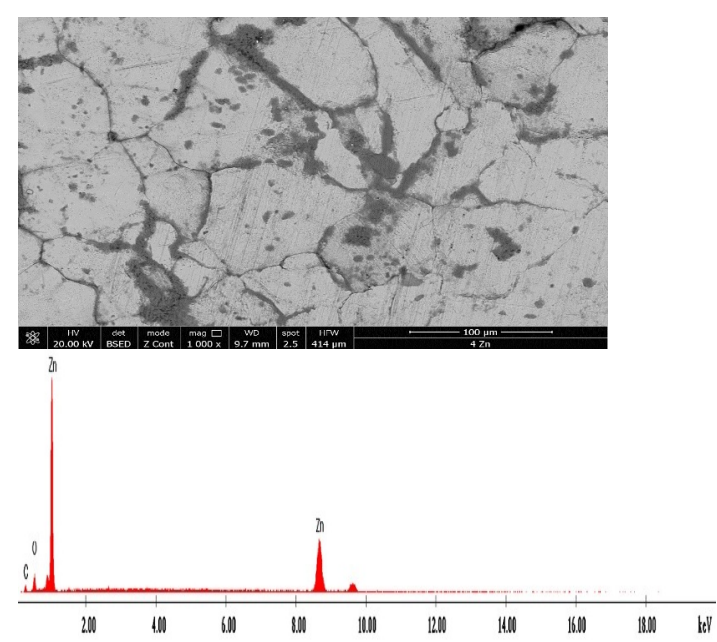

Fig. 12. SEM image (up) of initial specimen and EDX analysis

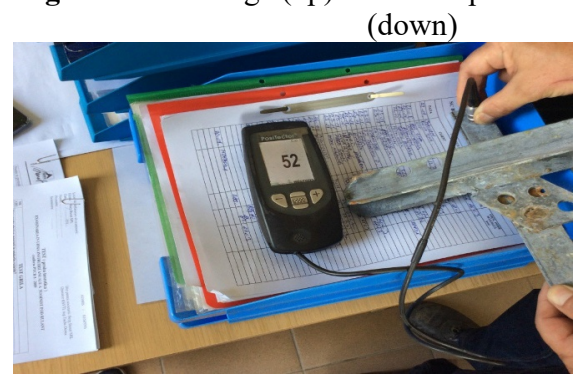

Fig. 13. Zinc thickness measuring device "PosiTector" [13]

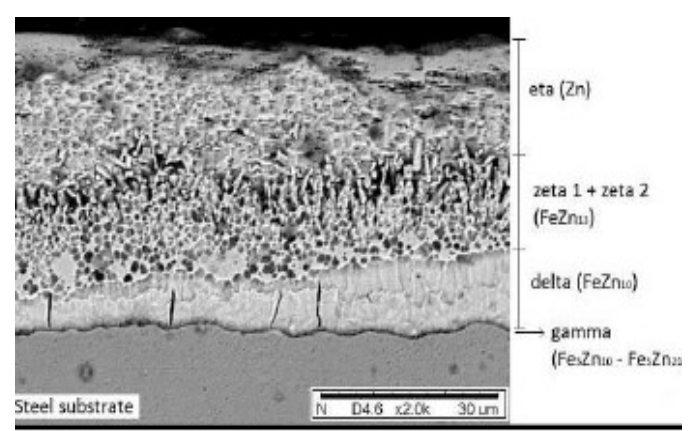

Fig 14. Microstructure of the zinc layer [14]

\section{Mathematical prediction}

In statistics, regression validation is the process of deciding whether the numerical results quantifying hypothesized relationships between variables, obtained from regression analysis, are acceptable as descriptions of the data. The validation process can involve analyzing the goodness of fit of the regression, analyzing whether the regression residuals are random, and checking whether the model's predictive performance deteriorates substantially when applied to data that were not used in model estimation. One measure of goodness of fit is the $\mathrm{R}^{2}$ (coefficient of determination), which in ordinary least squares with an intercept ranges between 0 and 1 . While a low $\mathrm{R}^{2}$ implies that the model does not fit the data well. In statistics, the coefficient of determination, denoted R2, is the proportion of the variance in the dependent variable that is predictable from the independent variable(s). In regression, the R2 coefficient of determination is a statistical measure of how well the regression predictions approximate the real data points. An R2 of 1 indicates that the regression predictions perfectly fit the data. In regression, the Null Hypothesis is that the coefficients associated with the (independent) variables is equal to zero. The alternate hypothesis is that the coefficients are not equal to zero (i.e. there exists a relationship between the independent variable in question and the dependent variable). When $p$ Value is less than significance level $(<0.05)$, we can safely reject the null hypothesis that the co-efficient $\beta$ of the predictor is zero.

\section{Data from Table 4}

a) Linear case $y=a+b * x$

(1)

\begin{tabular}{|l|l|l|}
\hline Parameter b & P-value & $\mathrm{R}^{2}$ coefficient \\
\hline-0.08509 & 0.434 & 0.2132 \\
\hline
\end{tabular}

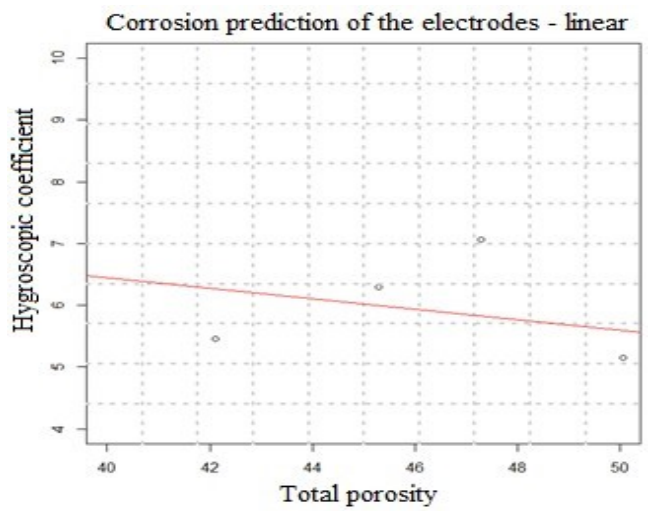

- The model is inappropiate.

b)The parabolic case $y=a+b * x+c^{*} x^{\wedge} 2(1)$

\begin{tabular}{|l|l|l|l|l|}
\hline $\begin{array}{l}\text { Parameter } \\
\mathrm{b}\end{array}$ & P-value & $\begin{array}{l}\text { Parameter } \\
\mathrm{c}\end{array}$ & P-value & $\begin{array}{l}\mathrm{R}^{2} \text { coefficien } \\
\mathrm{t}\end{array}$ \\
\hline 2.36555 & 0.371 & -0.02517 & 0.357 & 0.5381 \\
\hline
\end{tabular}




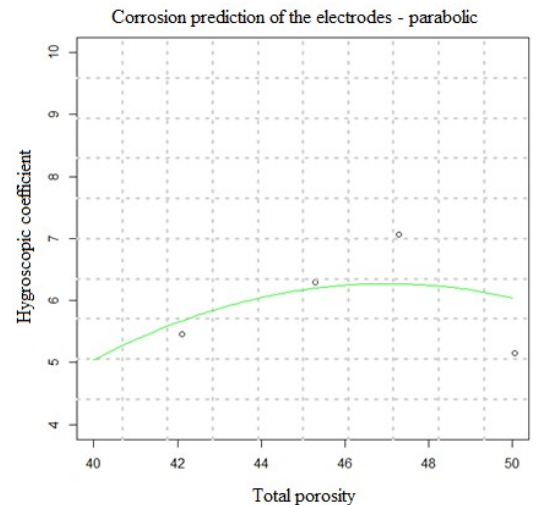

- The model is better than the linear one, but still inappropriate for our data.

c) Rational grade $\mathrm{I}, \mathrm{y}=(\mathrm{a} * \mathrm{x}) /(\mathrm{b}+\mathrm{x})$

(1)

\begin{tabular}{|l|l|l|l|l|}
\hline Parameter a & $\begin{array}{l}\text { P- } \\
\text { value }\end{array}$ & Parameter b & P-valoare & $\begin{array}{l}\mathrm{R}^{2} \text { coefficie } \\
\mathrm{nt}\end{array}$ \\
\hline 3.746 & 0.171 & -16.598 & 0.396 & 0.672 \\
\hline
\end{tabular}

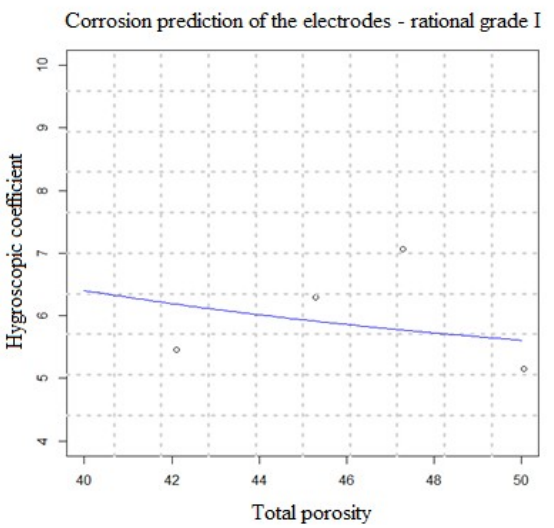

d) Rational grade II $y=\left(a^{*} x^{\wedge} 2+b^{*} x+1\right) /\left(b^{*} x^{\wedge} 2+1\right)$

\begin{tabular}{|l|l|l|l|l|}
\hline Parameter a & P-value & Parameter b & P-value & $\begin{array}{l}\mathrm{R}^{2} \text { coeffici } \\
\text { ent }\end{array}$ \\
\hline 0.10612 & 0.00462 & -9.64899 & 0.0053 & 0.9973 \\
& & & & \\
\hline
\end{tabular}

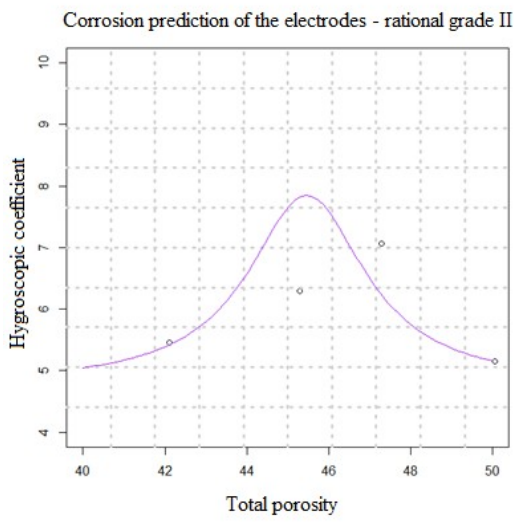

- The model is statistically appropriate.
2. Data from Table 5.

a) The linear case $y=a+b * x$

\begin{tabular}{|l|l|l|}
\hline Parameter b & P-value & $\mathrm{R}^{2}$ coefficient \\
\hline-0.3820 & 0.0782 & 0.7152 \\
& & \\
\hline
\end{tabular}

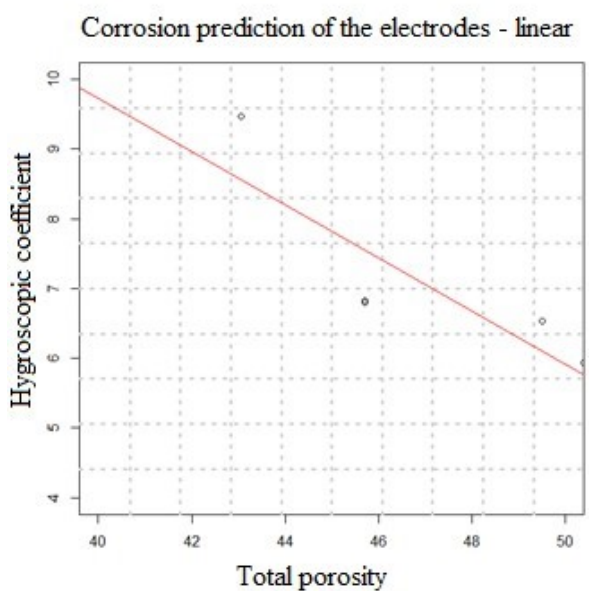

- The model is inappropriate

b) The parabolic case $y=a+b * x+c * x^{\wedge} 2$

\begin{tabular}{|l|l|l|l|l|}
\hline Parameter a & P-value & Parameter b & P-value & $\begin{array}{l}\mathrm{R}^{2} \text { coeffici } \\
\text { ent }\end{array}$ \\
\hline-10.4904 & 0.0930 & 0.1077 & 0.0911 & 0.9463 \\
& & & & \\
\hline
\end{tabular}

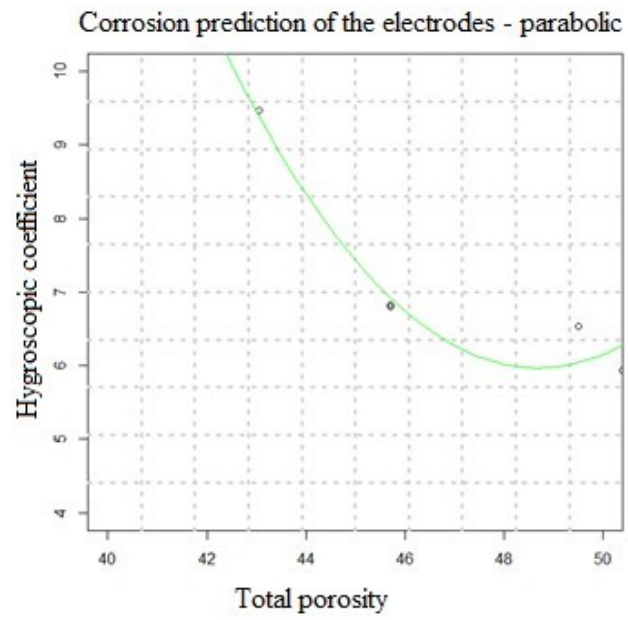

- The model is appropriate.

\section{Conclusion}

In conclusion, a regression model is appropriate if the Pvalue of the test $t$ is small (below an error threshold of 0.05 ) and the value of the coefficient of quantification as high as possible (closer to 1). 


\section{References}

1. https://ro.wikipedia.org/wiki/Timi\%C8\% 99oara;

2. Starea de sănătate a solurilor municipiului Timișoara, trecut, prezent, viitor. Contract de cercetare științifică încheiat de Primăria Municipiului Timișoara cu Facultatea de Agricultură din cadrul U.S.A.M.V.B., intitulat „Identificarea și evaluarea gradului de poluare a solurilor din zonele cu potențial...,

3. Consumatori de Energie Electrică, Materiale, Măsurări, Aparate, Instalații; autori: Nicolae GOLOVANOV, Ioan IONESCU, Nicolae MIRA, Petru POSTOLACHE, Cornel TOADER, Editura AGIR, București, 2009;

4. Manualul Instalațiilor Electrice, editura Colecția Tehnică, Schneider Electric, 2007;

5. Ghid de Aplicare-Calitatea Energiei Electrice, Legareala pamânt\&CEM, Instalații de legare la pământ-Bazele teoretice pentru calcul și proiectare, Prof.Henrzk Markiewicz\&Dr. Antoni Klajn, Wroclaw Universitz of Technology, iunie 2003, European Copper Institute (ECI) Societatea Inginerilor Energeticieni din România;

6. Normativ privind proiectarea, execuția, și exploatarea instalațiilor aferente clădirilor, Indicativ I7-2011;

7. Consumatori de Energie Electrică, materiale, măsurări, aparate, instalații, Nicolae GOLOVANOV, Ioan IONESCU, Nicolae MIRA, Petre POSTOLACHE, Cornel TOADER, editura AGIR 2009, ISBN 978-973720-240-6.

8. Manualul instalațiilor electrice, Schneider Electric România S.R.L., ediția Mai 2007, pg.E12;

9. ***http://www.creeaza.com/referate/geog rafie/geologie/PROPRIETATILE- FIZICE-SIFIZICO288.php;

10. st.drd. Alina SIMINA, Rezultate Laborator, Oficiul de Studii Pedologice şi Agrochimice filiala Timiş, 2018;

11. ANAZ România, Sustenabilitatea prin zincare termică, Cluj Napoca 15 noiembrie 2017, Prescrierea zincării termice în documentații: Folosirea SR EN ISO 1461în Managementul Calității, ing.Karol IONAȘ, S.C. BERG BANAT;

12. Universitatea de Științe Agricole și Medicină Veterinară a Banatului din Timișoara, Regele Mihai I al României;

13. S.C. BERG - BANAT S.R.L.;

14. Corrosion of Galvanized Steel Under Different Soil Moisture Contents, Roseana Florentino da Costa Pereira, Edkarlla Sousa Dantas de Oliveira, Maria Alice Gomes de Andrade Lima, Simone Louise Delarue Cezar Brasil, Materials Research. 2015; 18(3): 563$568 \quad$ DOI: http://dx.doi.org/10.15901439.341714;
15. ${ }^{* * *}$ https://ranslate.google.ro/translate?h $\mathrm{l}=$ ro\&sl=en\&u=https://en.wikipedia.org/wik i/Tafel_equation\&prev=search; 16. ${ }^{* * *}$ https://ro.wikipedia.org/wiki/An aliz\% 